Biologists are thus given the opportunity, by visiting the Collection, of comparing their own work with that of others. The preparations deposited remain the property of the depositors, who may at any time reclaim them.

\section{Science Reports of Tohoku University, Japan}

Reports from the Research Institute for Iron, Steel and Other Metals of Tohoku University, Sendai, Japan, used to regularly appear in a Tohoku University publication called Science Reports. Since 1944 and the issue of Vol. 32, this publication has been suspended. The Association of Research Institutes of Tohoku University has recently commenced the issue of a new set of Science Reports. This is divided into three sections, Series A, B and C, of which the first is devoted to physics, chemistry and metallurgy. The scientific and technological reports of the Research Institute for Iron, Steel and Other Metals will be printed in Series A. The first two numbers of Vol. 1, Series A, were published in May and August 1949.

\section{Earthquake Records at De Bilt, Netherlands}

Dr. F. A. Vening MeInesz, director-in-chief of the Royal Netherlands Meteorological Institute, states that, owing to war circumstances, the seismological station at $\mathrm{De}$ Bilt was not recording earthquakes during October 11, 1944-June 1, 1945. Fortunately, neither the instruments nor the building were damaged, and recording began again when electric power was available on June 1, 1945. The seismological bulletin issued for the period June 1-December 31, 1945 (Seismic Records at De Bilt, 33, 1945. Pp. vii+16. ('s-Gravenhage : Koninklijk Nederlands Meteorologisch Instituut, 1949.) 1 f.), shows 189 recorded earthquakes which could be interpreted and timed. The records have been reduced by Dr. J. Veldkamp, director of the Section for Terrestrial Magnetism and Seismology, and by Mr. J. Oldeman, scientific assistant. The instruments in action during the period were three Galitzin seismographs, one astatic Wiechert horizontal seismograph and two Bosch horizontal pendulums. The last three were, in general, interpreted only when necessary to supplement the Galitzin readings.

\section{Colonial Service: Recent Appointments}

THE following appointments in the Colonial Service have recently been announced: Dr. E. M. Chenery (soil chemist, Agricultural Department, Trinidad), chemist, Agricultural Department, Uganda; C. W. L. Fishlock (director of agriculture, British Honduras), senior agricultural officer, Tanganyika; G. M. Roddan (deputy director of agriculture, Kenya), director of agriculture, Nyasaland; R. R. Waterer (conservator of forests, Cyprus), conservator of forests, Kenya ; G. B. Smart (medical officer, Hong Kong), pathologist, Hong Kong; V. R. S. Beckley and W. R. Birch, agricultural officers, Kenya; A. E. Carlaw and M. J. W. English, agricultural officers, Tanganyika; J. M. B. Harley, research officer (entomologist), East Africa High Commission; E. W. King, agricultural officer, Uganda; H. H. Roberts, agricultural officer, Northern Rhodesia; E. T. Wilnot, agricultural officer, Nyasaland; D. N. Holt, geologist, Nyasaland ; L. D. Sanders, geologist, Kenya ; Dr. S. G. Cowper, pathologist, Mauritius; J. H. Caley, staff surveyor, Forest Department, Kenya ; R. S. Pinniget, veterinary officer, Tanganvika; D. P. Franklin, agricultural superintendent,
Nigeria; D. V. Mackenzie, assistant meteorologist, Nigeria.

\section{Announcements}

THe new building of the Imperial Forestry Institute, Oxford, will be opened by H.R.H. Princess Margaret on October 19.

The Council of the British Welding Research Association has awarded the Welding Research Prize for 1949 to Dr. K. Winterton, Mr. J. G. Ball and Mr. C. L. M. Cottrell for their joint paper entitled "A New Weldability Test for Magnesium Alloy Sheet". This Prize (£100) has been given by the British Oxygen Co., Ltd., which has offered to provide a prize fund for three years for a competition relating to welding. The closing date for entries for the 1950 competition has been extended to December 31, 1950. Further information can be obtained from the Secretary, British Welding Research Association, 29 Park Crescent, London, W.1.

Mr. PaUL Adorran, assistant managing director of Broadcast Relay Services, Ltd., has been elected president of the British Institution of Radio Engineers. Mr. Adorian, who was a student at the City and Guilds Engineering College, joined the Rediffusion group of companies in 1932 as a development engineer and was appointed chief enginoer in 1936. His main technical work has been on the development of relay systems and industrial electronics, and he has been directly associated with work on synthetic training methods for airmen.

Apporntments to the [Australian] National Standards Commission have been announced as follows: Chairman, Prof. L. G. H. Huxley (professor of physics, University of Adelaide); Members, Dr. G. H. Briggs (chief, Division of Physics, Commonwealth Scientific and Industrial Research Organisation). Mr. N. A. Esserman (chief, Division of Metrology, C.S.I.R.O.), Mr. W. M. Holmes (formerly superintendent of weights and measures, Victoria) and Mr. F. J. Lehany (chief, Division of Electrotechnology, C.S.I.R.O.). The Commission advises on the Commonwealth standards of measurement held at the National Standards Laboratory, Sydney, of the Commonwealth Scientific and Industrial Research Organization.

Sir George Beilby Memorial Fund awards, which are considered by administrators representing the Royal Institute of Chemistry, the Society of Chemical Industry and the Institute of Metals, are made at intervals to British scientific research workers, preference being given to investigations relating to the special interests of Sir George Beilby, including problems connected with fuel economy, chemical engineering and metallurgy. In general, the awards are granted to younger men and women for original work done over a period of years. In 1949 three such awards were made, each of 100 guineas. Awards may be made early next year, and the administrators request that their attention ke directed to outstanding work of the nature indicated not later than December 31. Communications should ke addressed to the Convener of the Administrators, Sir George Beilby Memorial Fund, Royal Institute of Chemistry, 30 Russell Square, London, W.C.I.

Erratum. In the communication "Monoclinic Thorium Silicate" by Prof. A. Pabst in Nature of July 22 , p. 157 , for the unit-cell dimension $c_{0}=$ $5.54 \mathrm{~A}$., read $c_{0}=6.54 \mathrm{~A}$. 